\title{
Invasive Wild Pigs: A Significant Disturbance in Coastal Forests
}

\author{
Elizabeth A. Bradley * (1) and Graeme Lockaby \\ School of Forestry and Wildlife Sciences, Auburn University, Auburn, AL 36849, USA; lockabg@auburn.edu \\ * Correspondence: eab0128@auburn.edu
}

check for updates

Citation: Bradley, E.A.; Lockaby, G. Invasive Wild Pigs: A Significant Disturbance in Coastal Forests. Forests 2021, 12, 1042. https:// doi.org/10.3390/f12081042

Academic Editors: William H. Conner and Thomas J. Dean

Received: 28 June 2021

Accepted: 3 August 2021

Published: 5 August 2021

Publisher's Note: MDPI stays neutral with regard to jurisdictional claims in published maps and institutional affiliations.

Copyright: (c) 2021 by the authors. Licensee MDPI, Basel, Switzerland. This article is an open access article distributed under the terms and conditions of the Creative Commons Attribution (CC BY) license (https:// creativecommons.org/licenses/by/ $4.0 /)$.

\begin{abstract}
Introduced in $~ 59$ countries and native across Europe and Asia, wild pigs, Sus scrofa, are the most wide-spread swine species in the world. As ecosystem engineers, wild pigs are a significant source of disturbance in introduced ecosystems due to their numerous, complex impacts on ecosystem processes. Wild pigs are often found in the resource-rich habitat of coastal forests. Coastal forests are complex, dynamic systems with tremendous biodiversity. Exposed to recurrent disturbances, the biophysical characteristics of coastal forests contribute to their ability to return to their original state post-disturbance. However, compounding disturbances can weaken this ability and threaten the health and function of the ecosystem. In this review, through the model of the forests of the southeastern United States Coastal Plain, we (1) describe conditions found across the forested coastal landscape, (2) describe wild pig disturbance, and (3) discuss how wild pig impacts can add to significant anthropogenic and climate-related disturbances threatening coastal forests. Through this review, we find that the impacts of wild pig disturbance on coastal forests often have similar effects as anthropogenic and climate change-related disturbances that may enhance these significant threats to coastal forest function and resiliency.
\end{abstract}

Keywords: coastal forests; invasive species; wild pigs; Sus scrofa

\section{Introduction}

Wild pigs, Sus scrofa, are a prolific and invasive species that cost $\$ 1.5$ billion in damage and control costs annually in the United States [1]. The negative impacts of wild pig foraging and predation are extensive, causing millions of dollars in agricultural damage and imperiling vulnerable native plant and animal species [2-4]. Additionally, wild pigs are ecosystem engineers with the potential to greatly influence and alter an ecosystem's natural processes, such as vegetation succession, nutrient cycling, and water quality; these impacts can have cascading impacts on the biodiversity and ecological systems of the areas in which they reside [2-7]. The severity and pervasiveness of the impacts of wild pigs are dependent on the density of wild pigs, the ecosystem type of their habitat, and the availability of food, cover, and water [4,6-9]. Temperate and tropical coastal forests within wild pigs' non-native range are the most likely ecosystems to experience severe and pervasive impacts from wild pigs due to the ecosystems' lack of adaptation to wild pigs, the increased biodiversity of these regions that are often endemic and imperiled, and the abundant food, water, and cover provided by the bottomland forests, riparian zones, and wetlands of coastal forests $[4,6,7,9]$.

Coastal forests are complex, dynamic systems that are essential to the function and resiliency of coastal regions globally [10]. Exposed to recurrent disturbances, the biophysical characteristics of coastal forests contribute to their resilience, which is the ability of an ecosystem to return to its original state post-disturbance [10]. Additional and compounding disturbances can create self-reinforcing feedback in systems that result in altered biophysical states; ecosystems that have shifted to altered states often lose the characteristics, function, and services provided by their original state [10-12]. As such, it is important to assess the impacts of other coastal forest disturbances, such as invasions of 
non-native species, alongside the more frequently discussed anthropogenic and climate change disturbances [13].

Half of the nation's 6 million wild pigs reside in the forests of the coastal plain of the southeastern region of the United States (Figure 1) [14]. Already home to the highest density of wild pigs in North America, the region is expected to have a significant increase in wild pig populations in the coming years (Figure 2). Populations of wild pigs are expected to increase the most in southeastern watersheds, with total watershed occupancy expected to reach $91.2 \%$ by 2025 [7]. The prevalence of wild pigs in the Coastal Plain is due to the abundance of cover, food, and water in the watersheds and wetlands in the region $[9,15]$. With greater than 1500 endemic plant species and 1/4 of all US vascular plants, there is no shortage of cover and food for wild pigs in the US Coastal Plain [16,17]. There is also abundant water for wild pigs in the region, as the US Coastal Plain is a 1.2 million $\mathrm{km}^{2}$ physiographic region characterized by broad alluvial features with floodplains and forests that experience frequent inundation [18].

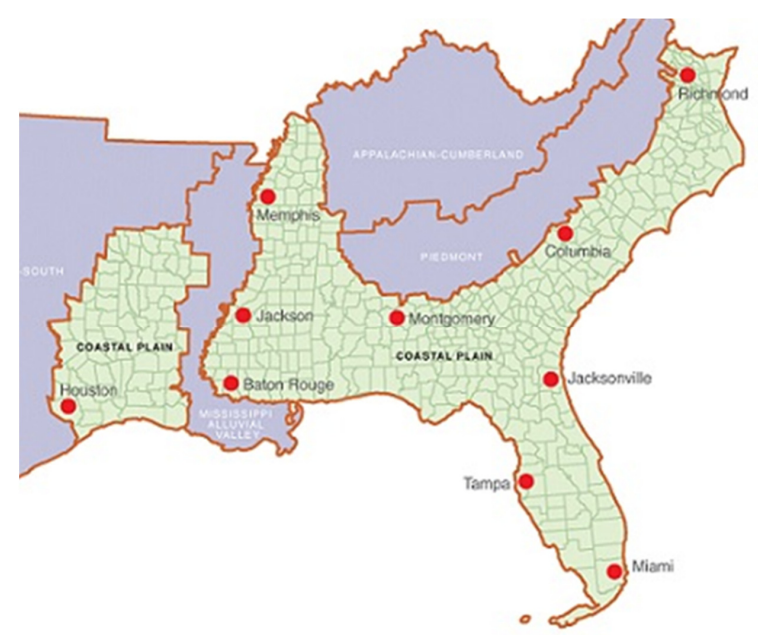

Figure 1. The coastal plain of Southeastern United States. Adapted from Hoyle, S. CompassLive-Klepzig, K., R. Shelfer, and Z. Choice. 2016. Forests of the South's Coastal Plain: The next 50 years. USDA Forest Service. Asheville, NC.

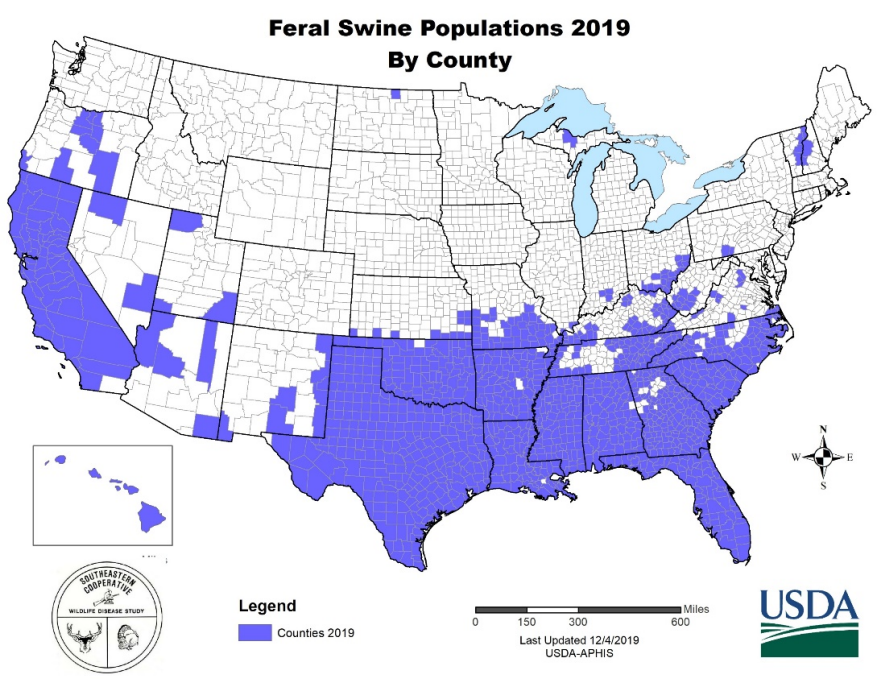

Figure 2. Feral Swine Populations 2019 by County. Reproduced with permission from USDA-APHIS, 2020.

Due to the abundance of resources for wild pigs and growing populations, we will be using the forests of the US Coastal Plain as a model for the impacts of wild pigs on coastal forests in their non-native range. In this review, we will (1) briefly describe conditions found 
across the forested coastal landscape, (2) describe wild pig disturbance, and (3) discuss how wild pig impacts are additive with other significant anthropogenic and climate-related disturbances threatening coastal forests. Through this review, we find that the impacts of wild pig disturbance on coastal forests often have similar effects as anthropogenic and climate change-related disturbances (albeit at different scales) which may enhance these significant threats to coastal forest function and resiliency.

\section{Methods}

During the spring of 2021, we searched numerous literature bases-Web of Science, BioOne Complete, Elsevier, and many others (see list of databases searched at https: / / www.lib.auburn.edu/find/bytitle.php, accessed from 15 May 2021). Within those literature bases, we conducted a Boolean search including (but not limited to) the terms: "wild pig", "Sus scrofa", "feral swine", "feral pig", "soil", "water", "vegetation", "forest", "regeneration", and others. Special attention was paid to results including the phrase 'coastal' or located in the forests of the Coastal Plain of the southeastern United States. Potential sources were reviewed by the authors to determine those that were comparable in geographical location, habitat type, and methodological approach. The findings of these sources, supporting or contrasting, were then synthesized for this paper. While the focus was on forests in the Coastal Plain of the southeastern United States, studies conducted outside of this region were used on occasion to emphasize the variability of the impacts of wild pigs. This was necessitated by the significant room for future study into the impacts of wild pigs on ecosystem function and ecological systems. Of the 119 citations used in our paper, 64 of the approximately 80 candidate citations were used in our synthesis. The remaining publications were studies that were not directly assessing the impacts of wild pigs on the forests of the Coastal Plain but contained relevant information about wild pigs, coastal forests, or disturbance ecology.

Additionally, the number of search phrases used to refer to wild pigs is the result of different terminology used by scientists across the globe. When discussing wild pigs in this paper, we are referring to Sus scrofa that are not being raised as part of the pork industry and can be found free roaming. Broadly speaking, wild pigs found in the Coastal Plain of the southeastern United States are descendants of pigs introduced to North America by Spanish Conquistadors, escaped domestic pigs, and more recent Eurasian stock brought to America by hunters [15]. While the origin of wild pig populations is sometimes considered when discussing wild pigs in North America, we found no significant evidence in our literature search indicating that the origin of introduction of wild pig populations influences the impacts that current populations have on natural ecosystems.

\section{Coastal Plain Forests}

The forests of the Coastal Plain are complex, dynamic systems of tremendous biodiversity and heterogeneity [16-19]. The soil complexity, vegetative productivity, and diversity of these systems were shaped over millions of years by the long growing seasons, temperate and wet climate, and disturbance regime that is characteristic of the region $[17,20,21]$. Hurricanes alter nutrient cycling, create soil microenvironments, influence vegetation composition, open canopy cover, influence successional order, and ultimately increase forest diversity [17,20-22]. The disturbance of hurricanes on coastal forests also influences fire risk within forests. Post-hurricane, there is an increase in fuel that can increase the risk of and sustain fire $[17,20,21]$. Historically, hurricanes, tropical storms, and fire were significant sources of disturbance in the region; however, current management has reduced the role of fire in the landscape $[17,20,21]$.

\subsection{Coastal Plain Forests: Soil}

The soils of the Coastal Plain are very diverse, with nine out of the twelve soil orders found in the region [16,19]. Utisols and alfisols are the most common orders found in the drier hydrology of upland areas, spodosols predominate in the wet pine flatwoods, 
and the tidal reaches of the region are predominated by histosols and mollisols $[23,24]$. The soils of the floodplains of the Coastal Plain are predominantly inceptisols, entisols, and histosols, and as a result there is considerable spatial variability in the horizonation, structure, texture, moisture, $\mathrm{pH}$, organic composition, decomposition rates, and nutrient cycling found in the region $[16,19,23,24]$.

\subsection{Coastal Plain Forests: Vegetation}

The approximately $478,000 \mathrm{~km}^{2}$ of forested land in the Coastal Plain are some of Earth's most biodiverse and productive forests [16-18,23]. Comprising $46-58 \%$ of the approximately $478,000 \mathrm{~km}^{2}$ of forest in the Coastal plain, pine species predominate the region's tree genera [23]. Located in the uplands of Coastal Plain forests, the primary pine species are longleaf (Pinus palustris), loblolly (P. taeda), slash (P. elliottii), and shortleaf (P. echinata) $[17,19,21]$. Occupying the largest proportion of the Coastal Plain and expected to increase in the coming decades, planted pine makes up $27 \%$ of forests in the Coastal Plain [23]. Loblolly pine (P. taeda) is the most commonly planted pine species in the region, although there are efforts to regenerate longleaf pine (P. palustris) whenever feasible. However, the Coastal Plain abounds with a wide variety of other tree and understory species. These species include turkey oak (Quercus laevis), blackjack oak (Q. marilandica), live oak (Q. virginiana), post oak (Q. stellata), southern red oak (Q.falcata), water oak (Q. nigra), willow oak (Q. phellos), pignut hickory (Carya glabra), red hickory (C. ovalis), mockernut hickory (C. alba), black-gum tupelo (Nyssa sylvatica), swamp tupelo (N. biflora), water tupelo (N. aquatica), bald cypress (Taxodium distichum), and pond cypress (T. ascendens) [23,25]. Making up just $20 \%$ of the forests in the region, bottomland hardwood forests are found along rivers and streams in the region, exhibit high productivity, and contain the greatest diversity of all forest cover types in the Coastal Plain $[17,21,23,26]$.

\section{Wild Pigs}

First introduced to North America by Spanish conquistadors, wild pigs, S. scrofa, quickly became established in forests of the Coastal Plain due to the abundance of cover, food, and water [15]. One of the most costly and destructive invasive species in North America, wild pigs are a significant potential threat to the forests of the Coastal Plain due to their preferential habitat selection and high density in the region $[1,9,15,27]$. As ecosystem engineers, wild pigs have the potential to greatly influence and alter the natural processes, biodiversity, and ecological composition of the forests of the Coastal Plain through the cascading impacts of their disturbance [2-7]. Their impacts are largely the result of their rooting behavior, predation, and influence on water quality. As the rate of population growth of wild pigs continues to increase in the southeast, the impacts of wild pig disturbance on coastal forests are projected to increase significantly $[15,28]$.

\subsection{Impacts of Wild Pigs: Soil}

One of the primary foraging techniques of wild pigs is rooting; rooting is the behavior in which an individual pig will use their snout to upturn soil in a manner similar to the use of a spade in order to locate subterranean food [9]. Rooting is most common where damp soils are available, and this preference has been observed in forested and non-forested habitats globally across their native and non-native ranges [29-31]. The tendency of wild pigs to root most commonly in damp soils suggests that the impacts of wild pig rooting will most significantly impact the damp soils of the bottomland forests of the Coastal Plain.

Rooting is theorized to alter soil properties; however, few studies seek to determine the impacts of wild pigs on soil properties, particularly in the Coastal Plain $[4,6]$. The few studies evaluating the impacts of wild pigs on soil characteristics are scattered across different regions and soil types globally, as such results are often conflicting. In theory, the upturning of soil by rooting increases soil aeration and respiration, reduces bulk density, mixes soil horizons, mixes leaf litter into the soil, and increases soil moisture. These impacts facilitate increased leaching of nutrients, increased decomposition rates, and accelerated 
nutrient mobilization and cycling. While the literature is conflicting, most studies have shown that rooting can mix soil horizons and mix leaf litter into the soil [31-38]. As the depth of soil horizons and leaf litter can be extremely variable, it is unsurprising that other studies have found no mixing of soil horizons as rooting rarely impacts more than a few centimeters of soil [34]. Whether this alters soil respiration is largely unknown; however, there is some evidence to support the idea [4,39]. The upturning of soil by rooting has been shown to decrease bulk density as well [40]. Most studies have found no impact on soil texture and moisture [4,41-44]. The most agreed upon impact of wild pigs on soil characteristics in the literature are the influences on nutrient mobilization and acceleration of nutrient leaching, particularly calcium, phosphorous, magnesium, and ammonium, as a result of increased decomposition rates [36,40,45-47]. However, this influence is likely dependent on the characteristics of the rooted area, the methodology used, and the local climate. So, it is not surprising that other studies have found no effect from rooting on organic matter, decomposition rates, nitrogen content, or $\mathrm{pH}$ of soils $[34,41-44,48]$.

Wild pigs do not influence soil through rooting alone. Monogastric ruminants, wild pigs preferentially select forage with starch, simple sugars, and protein due to their difficulty digesting structural carbohydrates and cellulose $[9,49]$. As a result, wild pigs are drawn to areas, such as coastal forests, with abundant invertebrates [3]. Wild pigs frequently encounter invertebrates and have been shown to consume them three times as often as they consume vertebrates [50]. Opportunistic omnivores, wild pigs will exploit a resource when they find a high-yield forage, for example consuming up to $93 \%$ of earthworms at a site [51]. This type of intense exploitative foraging can result in significant alterations in soil dynamics. Soil invertebrates help create and support the aggregation of soil and structural porosity, contribute to the decomposition of organic waste, control microbial communities, and contribute to countless other physical and biochemical processes in soil [52]. Although studies are scarce, results from predation studies in the Coastal Plain support further study into the soil impacts of invertebrate consumption by wild pigs [29,30,32]. Significant alterations to soil dynamics resulting from the impacts of wild pigs can have cascading effects on soil chemistry and composition, as has been shown in both their native $[50,53,54]$ and non-native range $[29,30,36,42,55]$.

While the current literature is limited, evidence supports the idea that wild pigs have significant potential to disrupt the processes and function of soils in the forests of Coastal Plains. However, the significance of this disruption is likely a function of the spatial distribution and extent of impacts [4,6-9].

\subsection{Impacts of Wild Pigs: Vegetation}

As explained, the Coastal Plain is a region with abundant and biodiverse vegetation resulting from the variability of ecosystem conditions. Providing abundant cover and forage, the region's vegetation is a primary contributor to the success of wild pigs [15]. Much like the variability in vegetation type, the extent of the impacts of wild pigs on vegetation varies significantly. From subtle shifting of plant populations to completely shifting vegetation composition from a diverse community to a monotypic stand, wild pigs are a source of significant disturbance for plant communities [4,45]. Wild pigs impact vegetation through two major pathways: foraging and facilitating the spread of invasive species.

Foraging by wild pigs is one of the primary ways that wild pigs impact vegetation composition. As generalist, opportunistic omnivores, the versatility of the diet of wild pigs significantly contributes to their success on an international scale $[3,4,6]$. Wild pigs are capable of consuming animal matter but get $80-90 \%$ of their nutrition from plant matter $[2,15,32,33,36,46,56]$. Alongside the predation of aboveground vegetation, wild pigs forage for vegetation underground through rooting. As rooting can result in mortality for vegetation upturned during their foraging, the impacts of foraging by wild pigs do not occur through direct predation alone. The joint impacts of foraging and rooting by wild pigs are density-dependent [36]. High-density wild pig populations are linked with increased rooting intensity, which can be as high as $80 \%$ of the available area annually [36]. This can 
have significant impacts on forest vegetative composition. Rooting reduces plant growth, survival, cover, reproduction, and species diversity [2-4,27,31,36,38,40,46,57-59]. While the impacts of wild pigs on species diversity are often debated, evidence strongly suggests that they reduce native species diversity in the Coastal Plain $[9,15,58]$. Wild pigs are also intensive consumers of seedlings, mast, and saplings, which has significant impacts on vegetation composition in coastal forests as it alters the spatial distribution, regeneration, and recruitment of species [6,32,34,36,50,60-62]. Over time, these alterations to spatial distribution, regeneration, and recruitment of species can influence the canopy of a forest, as it can effectively halt the establishment of new young trees [63]. Additionally, the impacts of foraging by wild pigs can result in the local extinction of plant species [7,61,64-67]. Local extinctions permanently alter the composition of the plant community, which can have significant and cascading impacts on the health and function of the ecosystem $[7,68]$. As an example, in the Coastal Plain of Texas, the effects of pig exclusion on forest dynamics were compared to that of unfenced areas [58]. The study area was dominated by oaks, but numerous other tree species were also present. Exclusion of wild pigs for seven years was associated with increased growth of saplings and increased species richness. Tree species with large seeds, such as oak and hickory, were more common in fenced areas due to the exclusion of pigs feeding there. The authors suggested that the latter finding implies that large seed consumption by pigs may be altering the species composition of the understory and potentially the overstory.

The second major impact of wild pigs on vegetation is their facilitation of the spread of invasive species. Wild pigs, an invasive species themselves, significantly contribute to the spread of invasive plant species globally through endozoochory seed dispersal, epizoochory seed dispersal, and rooting [2,4,43,69-71]. They disperse seeds throughout their range through the ingestion and excretion of seeds (endozoochory) and through the dispersal of seeds that adhere to their fur (epizoochory) [2,4,69,71-73]. Wild pigs are extremely successful at dispersing non-native and invasive plant species through endozoochory with studies showing exotic species comprised as many as $91 \%$ of seedlings dispersed by them [72]. While the literature on epizoochory is limited, a study of wild pigs has shown that as many as $59 \%$ of seedlings dispersed by epizoochory were non-native [72]. Not only do wild pigs spread significant quantities of non-native and invasive species, but they also spread them across long distances. Through their seasonal movement from uplands to lowlands in search of food and water, as well as the long-distance movement of boars during the breeding season, wild pigs facilitate the spread of invasive plant species across areas of different habitats and land use [9,50,69,74].

In addition to the dispersal of large quantities of non-native plant seedlings, wild pigs facilitate the spread of invasive plant species through rooting, which creates conditions ideal for the establishment and success of invasive species. It is well established that disturbance events often favor non-native and invasive species because they reduce competition from other species, stimulate germination, and alter the availability of resources, such as water, light, and nutrients [75,76]. Invasive species take advantage of the impacts of disturbance due to higher growth rates, shorter dormancy requirements, increased germination rates, and increased reproduction rates $[12,68,75,76]$. As discussed earlier, wild pigs are extremely opportunistic omnivores that will exploit high-value resources. As a result, pig-rooting, as a foraging technique, often leads to significant alterations to spatial distribution, reductions in plant cover, reproduction, and growth, and can contribute to local extinction; all of these impacts reduce competition for resources and increase the available space for invasive plants to become established in $[7,61,64,66,69,77]$. Similarly, the impacts of wild pigs on vegetative regeneration may also facilitate the establishment of invasive plant species by reducing competition and opening canopy cover in extreme cases [63,69]. Additionally, wild pigs may alter canopy structure of native forests to the extent that regeneration environments become more hospitable to invasive plant species [58]. The impacts of rooting on soil dynamics also contribute to the establishment and success of non-native plants $[69,78,79]$. Repeated disturbance to vegetation and soil dynamics by wild pigs can 
facilitate the long-term dominance of invasive plant species [80]. The results of this type of long-term dominance vary by habitat and condition type, but evidence suggests that these types of invasions can lead to significant shifts in ecosystem dynamics and function as it alters existing ecosystem interactions, such as mutualistic interactions [81-84].

\subsection{Impacts of Wild Pigs: Water Quality}

Just as significant of a disturbance as predation and rooting, wild pigs greatly influence the water quality of the regions in which they inhabit. Unable to effectively thermoregulate, wild pigs spend significant time in and around water sources, where they wallow, drink, forage, and defecate [9]. As the hosts and potential vectors of $87 \%$ of swine pathogens causing clinical disease in livestock, poultry, wildlife, and humans, wild pigs play a significant role in pathogen transmission cycles [85-87]. The surface waters of Coastal Plain forests are ideal environments for pathogens associated with wild pigs, particularly enteric bacteria, due to the warm and temperate conditions, organic soils, and nutrient cycles common to the region [88]. Alongside the region's natural suitability to pathogen survival and prevalence, wild pigs facilitate survivorship and persistence of pathogens by increasing enteric bacteria levels (such as Escherichia coli), increasing nutrient availability, nutrient levels, biological oxygen demand, and turbidity and sedimentation [28,29,40,89-91]. The suitability of the region for elevated pathogen levels is significant. In low-order streams of the Alabama coastal forest, E. coli levels were found in to be as high as those of urban streams following storms that result in sewer overflow [90,92]. Decreases in base flow result in greater concentrations of pathogens per $\mathrm{mL}$, which increases the chance of the consumption of disease-causing loads of pathogens by animals [93]. Increases in surface water temperatures can also increase the risk of pathogen transmission as warmer temperatures facilitate higher pathogen survival and growth [93]. Additionally, the consumption of aquatic invertebrates by wild pigs can also result in changes to nutrient cycling in streams, which can further support pathogen survival and prevalence in surface waters $[29,30]$. Predicted to rise by $18.3 \%$ to a total of $91.2 \%$, watershed occupancy of wild pigs in the southeastern US is rising [7]. As a result, the impacts of wild pigs on water quality in Coastal Plain forests are also expected to increase [7]. In areas associated with significant populations of wild pigs, the long-held paradigm that forested watersheds provide clean enough water for reference systems may be in question.

\section{Coastal Forests, Wild Pigs, and Other Recurring Disturbances}

When disturbances have similar influences on natural processes, they may add to and compound the intensity of their impacts, particularly if a disturbance facilitates another. This can overwhelm an ecosystem's set of self-reinforcing feedbacks that allow it to return to its original state, which may result in a shift to an altered one [10,12,75,94]. Altered ecosystem states have different conditions and processes, which can reduce or eliminate the ecological function and service of the original state $[10,75,94]$. The increasing impacts of climate change and anthropogenic disturbances, such as increasing storm severity and urbanization, on forests of the Coastal Plain are likely to alter coastal forests to varying severities, which is a scenario exacerbated by the declining distribution of forests in this region. We suggest that wild pigs, through their many influences on coastal forest functions, may exacerbate the severity of these impacts.

Although a region adapted to a recurrent disturbance regime, the coastal forests of the US Coastal Plain are increasingly subject to growing pressures from anthropogenic and climate change-related disturbances $[10,12,17,21,23,95,96]$. Climate change is expected to result in increasing precipitation and temperature variation across the region resulting in elevated stress on the health and function of coastal forests; urbanization is also linked with changing precipitation patterns and temperature variation in the region [97-99]. Climate change is also expected to increase the risk of hurricanes and fire in the region, and has already been linked with rising frequency and severity of these natural disturbances $[10,13,20,21,96,100-102]$. The Coastal Plain is characterized by high frequencies of 
hurricanes and tropical storms. These storms have exerted a strong influence on coastal forests in terms of species composition and other attributes [103]. As temperatures rise and precipitation shifts due to climate change, the intensity and frequency of storms striking the Coastal Plain are expected to rise [101]. Additionally, climate change is likely to reduce the extent of tidal forests in the Coastal Plain as a result of its vulnerability to sea level rise; the level of risk of the region for this ranges from moderate to very high [101]. Areas with the greatest risk include the Alabama coast, the coast of Louisiana and Texas, the south Atlantic coast of Florida, and the coasts of South Carolina, North Carolina, and Virginia [101]. The sea level rise in this region is caused primarily by land subsidence and can be expected to alter and destroy some coastal forests through the influx of salinity.

Over the next 40 years, it is expected that the human population in the Coastal Plain will increase by $64 \%$, urban land use will increase by $142.2 \%$, and forested land will decrease by $11.7 \%[17,23,95,102]$. Decreasing forested land and increasing urbanization associated with rising human populations are likely to worsen the existing anthropogenic pressures on coastal forests $[10,12,17,21,23,95]$. The extent of coastal forests will decline as land-use changes. Consequently, increasing populations of wild pigs will inhabit a smaller distribution of coastal forests, which may increase the density of wild pigs in many areas. These trends suggest that increased densities will translate into increased degradation of water quality, more pronounced impacts on vegetation dynamics, intensified pressures on invertebrates, small animals, and endangered species, and increased facilitation of the spread of invasive species. As such, it is important to evaluate whether the growing populations of wild pigs contribute to the impacts on soil, vegetation, and water that may result in permanently altered coastal forests. Additionally, it will become imperative to evaluate whether management strategies can decrease the pressures on coastal forests influenced by wild pigs, climate change, and urbanization.

\subsection{Compounding Disturbance: Soil}

One of the major anthropogenic impacts on coastal forests is the impacts of urbanization. Urbanization is associated with: increases in soil temperature, soil moisture dynamics, macroinvertebrates such as earthworms, decomposition rates, nitrogen-mineralization, and nitrification rates, and decreases in microinvertebrate populations, fungal communities, stem density, and leaf litter depths are just a few of the impacts of urbanization $[10,12,17,21,23,95]$. As explored earlier, wild pigs are associated with increases in soil temperature, decomposition rates, macroinvertebrate populations, nitrogen mineralization, and nitrification rates; they also decrease microinvertebrate populations, leaf litter depth, stem density, and alter fungal communities [31-38,40,45-51,53-55]. As each of these alterations has cascading impacts on soil dynamics and nutrient cycling, these alterations can result in significant alterations to the function of soil as well as to the composition and distribution of vegetation. Further research should seek to answer many of these under-explored soil dynamic disturbances caused by wild pigs, particularly in Coastal Plain forests.

\subsection{Compounding Disturbance: Vegetation}

The influence on vegetation by wild pigs are arguably the influence that is most likely to be a compounding or additive disturbance due to great similarities in the nature of impacts by wild pigs, climate change, and anthropogenic disturbances such as urbanization. Wild pig, climate change, and anthropogenic disturbances can compound in their direct impacts on vegetation as well as their facilitation of the spread of invasive species.

As previously explained, wild pigs directly influence vegetation composition, open canopy cover, influence successional order, and reduce species diversity $[2-4,9,15,27,31$, $36,38,40,46,57-59]$. Similarly, hurricanes influence vegetation composition, open canopy cover, influence successional order, and influence forest diversity in the US Coastal Plain [17,20-22]. Although a less common disturbance, fire disturbance alters nutrient cycling, influences soil dynamics, alters vegetation composition, opens forest floor, in- 
fluences successional order, and ultimately increases forest diversity in similar ways as wild pigs and climate change-related disturbances such as hurricanes [12,16,17,19-21]. Wild pigs also influence the spatial distribution, regeneration, and recruitment of forest species [6,32,34,36,50,60-62]. Over time, these alterations to spatial distribution, regeneration, and recruitment of species can effectively halt the establishment of new young trees [63]. This influence over the regeneration of coastal forests may facilitate and enhance the impacts that climate change is having on forest regeneration. Shifts in seasonality resulting from climate change are having significant impacts on the mast production and regeneration of forests $[104,105]$. While these impacts may not be a significant concern for some forests, studies have shown that pigs will exploit annual mast production and thus can prevent any regeneration $[2,9,63,104]$.

\subsection{Compounding Disturbance: Invasive Species}

The US Coastal Plain is a region of tremendous biodiversity; however, like many regions of high biodiversity, it is disproportionately impacted by the invasion of nonnative species as the conditions that support such high biodiversity are also ideal for invasive species [106]. The abundance of nutrients, temperate weather, and recurrent disturbance regime that supported the evolution of the region's biodiversity facilitate the spread of invasive species [16-22,68,75,76,81,107]. As such, the impacts of the disturbances resulting from wild pigs adds to the increasing effects of anthropogenic and climate change disturbance. Future research linking the influence on the spread of these three disturbances is needed and likely to produce significant results.

As wild pigs move about the Coastal Plain, they are facilitating the movement of invasive plant species, particularly to bottomland forests where they spend much of their time $[4,9,69]$. As discussed, wild pigs alter the habitat and reduce native plant growth, survival, cover, reproduction, and species diversity [2-4,27,31,36,38,40,46,57-59]. Similarly, urbanization and extreme weather events, such as hurricanes, also reduce native plant growth, reproduction, and cover $[20,22,107]$. Post-hurricanes, coastal forests in the US Coastal Plain lose approximately $10 \%$ of total annual sequestered carbon through downed biomass, which feeds back into the climate change cycle contributing to future climate change disturbance [96]. This downed biomass provides feedback to the wild pig issue, as they are drawn to the invertebrates associated with coarse woody debris [60,96]. As wild pigs are successful seed dispersers of invasive species, the increase in coarse woody debris in the post-hurricane forest brings in the invasive seedlings that wild pigs carry as they seek invertebrates in the decaying coarse woody debris. A similar effect likely results from the new growth emerging from the decreased canopy cover. Introduced invasive plant species can then take advantage of the post-hurricane decrease in canopy cover and decreased ground cover resulting from wild pig predation gaining a competitive advantage [107]. The decrease in canopy and ground cover reduces competition and increases resource availability, which allows the establishment and success of invasive plant seedlings [76]. Once introduced, invasive plant species are well equipped to spread along the abundant rivers and roads of the region $[108,109]$. This then results in the process repeating and spreading into areas less influenced by the hurricane, as pigs are also well documented to travel and forage along rivers and roads [110].

The spread of invasive plant species often facilitates the spread of co-occurring nonnative pathogens, microbes, insects, and fungi $[84,111,112]$. These co-occurring species alter the soil and habitat to make it less suitable for native species; this, in turn, further facilitates the establishment and success of invasive plant species [111,113,114]. Furthermore, wild pigs are very competent at spreading invasive species across long distances [84]. As such, the presence of wild pig populations likely increases the susceptibility of coastal forests to invasion by non-native plants, fungi, insects, and pathogens. This is significant as climate change and urbanization are also linked with the increased susceptibility to fungi, pathogens, and insects [115-117]. The spread of invasive species and their co-occurring pathogens and pests could be a serious threat to the planted forests that comprise $27 \%$ 
of forests in the US Coastal Plain [23]. Weakened as a result of increasing anthropogenic and climate change disturbance, some native coastal forest species are more vulnerable to hurricanes and less likely to compete successfully with invasive species [22]. Future studies should evaluate these potential compounding disturbances soon as both human and wild pig populations will increase in the coming decades alongside an increase in the impacts of climate change.

\subsection{Compounding Disturbances: Water Quality}

Forested watersheds have long been considered to be likely sources of reasonably clean water, and this function of coastal forests will continue to be generally true. It is also well-established that urbanization, agriculture, and other anthropogenic activities often degrade water quality. These disturbances are going to continue to degrade water quality. However, wild pigs are also an emerging non-point source water quality pollutant. This impact will increase as wild pig populations increase and costal forests decrease. Climate change is predicted to disturb natural floodplain dynamics through increased surface water temperatures, decreased base flow, and alterations to current hydroperiod patterns [118]. These impacts to natural floodplain dynamics include disruptions to floodplain vegetation [118]. Disturbance of streamside vegetation by climate change and wild pigs can reduce the vegetative buffer that helps reduce sedimentation, resuspension of pathogens, and surface transport of pathogens [91,118]. The lack of vegetative buffer can increase the impacts of storm flow runoff, which has been shown to increase due to climate change and urbanization [118,119].

Since so many of the impacts of wild pigs have the potential to add to the increasing anthropogenic and climate change-related disturbances already threatening the region, future research should evaluate these potential interactions. The results of such studies would inform management efforts of the forests of the Coastal Plain, both native and planted.

\section{Conclusions}

Forest resources of the southeastern US Coastal Plain face an uncertain future that is likely to become increasingly unstable. It is clear that the amount of forested land in the Coastal Plain will decrease in the coming decades due to urbanization and, to a lesser extent, sea level rise. It is also clear that climate will continue to shift in the region, leading to temperature rises, increased precipitation variability, and increased frequency and intensity of weather events, such as hurricanes. These disturbances will result in alterations to the region's vegetation composition, biogeochemistry, and water quality. The combination of these alterations will facilitate the spread of invasive species, which will in turn enhance the same disturbances that facilitated their establishment and success. To an increasing extent, wild pigs will contribute to these disturbances, particularly in terms of their influence on vegetation, soils, water, and animals and human health. In some instances, such as the spread of invasive species and risks to human and wildlife health, wild pigs are facilitating disturbances. Similarly, other disturbances, such as urbanization and climate change, facilitate and intensify wild pig disturbances. So, as wild pig populations rise alongside the impacts of urbanization and climate change, the impacts of wild pig disturbances will continue to increase and become more pronounced. As natural resource stakeholders and managers in the Coastal Plain, we must remain aware of the growing influence of wild pigs on our forests and investigate management strategies to counteract their impacts.

Author Contributions: E.A.B. and G.L. conceived and designed the paper; E.A.B. and G.L. performed the investigation; E.A.B. and G.L. reviewed the results; E.A.B. and G.L. wrote the article; E.A.B. and G.L. contributed to the edits and revisions. Both authors have read and agreed to the published version of the manuscript.

Funding: This research received no external funding.

Institutional Review Board Statement: Not applicable. 
Informed Consent Statement: Not applicable.

Data Availability Statement: The data presented in this study are openly available from the databases listed at: https:/ / www.lib.auburn.edu/find/bytitle.php.

Conflicts of Interest: The authors declare no conflict of interest. The funders had no role in the design of the study; in the collection, analyses, or interpretation of data; in the writing of the manuscript, or in the decision to publish the results.

\section{References}

1. Pimental, D. Environmental and economic costs of vertebrate species invasions into the United States. In Managing Vertebrate Invasive Species, Proceedings of the An International Symposium, Fort Collins, CO, USA, 7-9 August 2007; University of NebraskaLincoln: Lincoln, NE, USA, 2007; p. 8.

2. Strickland, B.K.; Smith, M.D.; Smith, A.L. Wild Pig Damages to Resources. In Invasive Wild Pigs in North America: Ecology, Impacts, and Management; VerCauteren, K.C., Beasley, J.C., Ditchkoff, S.S., Mayer, J.J., Roloff, G.J., Strickland, B.K., Eds.; CRC Press: Boca Raton, FL, USA, 2019; pp. 143-174. ISBN 978-1-315-23305-5.

3. Massei, G.; Genov, P.V. The Environmental Impact of Wild Boar. Galemys 2004, 16, 135-145.

4. Barrios-Garcia, M.N.; Ballari, S.A. Impact of Wild Boar (Sus Scrofa) in Its Introduced and Native Range: A Review. Biol. Invasions 2012, 14, 2283-2300. [CrossRef]

5. Crooks, J.A. Characterizing Ecosystem-Level Consequences of Biological Invasions: The Role of Ecosystem Engineers. Oikos 2002, 97, 153-166. [CrossRef]

6. Genov, P.V.; Focardi, S.; Morimando, F.; Scillitani, L.; Ahmed, A. Ecological impact of wild boar in natural ecosystems. In Ecology, Conservation and Management of Wild Pigs and Peccaries; Melletti, M., Meijaard, E., Eds.; Cambridge University Press: Cambridge, UK, 2018; pp. 404-419.

7. McClure, M.L.; Burdett, C.L.; Farnsworth, M.L.; Sweeney, S.J.; Miller, R.S. A Globally-Distributed Alien Invasive Species Poses Risks to United States Imperiled Species. Sci. Rep. 2018, 8, 5331. [CrossRef] [PubMed]

8. Fagiani, S.; Fipaldini, D.; Santarelli, L.; Burrascano, S.; Vico, E.D.; Giarrizzo, E.; Mei, M.; Taglianti, A.V.; Boitani, L.; Mortelliti, A. Monitoring Protocols for the Evaluation of the Impact of Wild Boar (Sus Scrofa) Rooting on Plants and Animals in Forest Ecosystems. Hystrix It. J. Mamm. 2014, 25, 31-38. [CrossRef]

9. Gray, S.M.; Roloff, G.J.; Montgomery, R.A.; Beasley, J.C.; Pepin, K.M. Wild Pig Spatial Ecology and Behavior. In Invasive Wild Pigs in North America: Ecology, Impacts, and Management; VerCauteren, K.C., Ditchkoff, S.S., Beasley, J.C., Mayer, J.J., Roloff, G.J., Strickland, B.K., Eds.; CRC Press: Boca Raton, FL, USA, 2019; pp. 33-56. ISBN 978-1-315-23305-5.

10. Martinez, M.L.; Taramelli, A.; Silva, R. Resistance and Resilience: Facing the Multidimensional Challenges in Coastal Areas. J. Coast. Res. 2017, 77, 1-6. [CrossRef]

11. Jiang, J.; Gao, D.; DeAngelis, D.L. Towards a Theory of Ecotone Resilience: Coastal Vegetation on a Salinity Gradient. Theor. Popul. Biol. 2012, 82, 29-37. [CrossRef]

12. Hobbs, R.J.; Huenneke, L.F. Disturbance, Diversity, and Invasion: Implications for Conservation. Conserv. Biol. 1992, 6, 324-337. [CrossRef]

13. Klein, R.J.T.; Nicholls, R.J. Assessment of Coastal Vulnerability to Climate Change. Ambio 1999, 28, $182-187$.

14. Mayer, J.J. Estimation of the Number of Wild Pigs Found in the United States; Savannah River Site (SRS): Aiken, SC, USA, 2014.

15. Mayer, J.J.; Beasley, J.C.; Boughton, R.K.; Ditchkoff, S.S. Wild Pigs in Southeastern North America. In Invasive Wild Pigs in North America: Ecology, Impacts, and Management; VerCauteren, K.C., Beasley, J.C., Ditchkoff, S.S., Mayer, J.J., Roloff, G.J., Strickland, B.K., Eds.; CRC Press: Boca Raton, FL, USA, 2020; pp. 369-402.

16. Noss, R.F.; Platt, W.J.; Sorrie, B.A.; Weakley, A.S.; Means, D.B.; Costanza, J.; Peet, R.K. How Global Biodiversity Hotspots May Go Unrecognized: Lessons from the North American Coastal Plain. Divers. Distrib. 2015, 21, 236-244. [CrossRef]

17. Mitchell, R.J.; Duncan, S.L. Range of Variability in Southern Coastal Plain Forests: Its Historical, Contemporary, and Future Role in Sustaining Biodiversity. Ecol. Soc. 2009, 14, 17. [CrossRef]

18. Hupp, C.R. Hydrology, Geomorphology and Vegetation of Coastal Plain Rivers in the South-Eastern USA. Hydrol. Process. 2000, 14, 2991-3010. [CrossRef]

19. Peet, R.K. Ecological Classification of Longleaf Pine Woodlands. In Longleaf Pine Ecosystem; Anderson, B.N., Howarth, R.W., Walker, L.R., Jose, S., Jokela, E.J., Miller, D.L., Eds.; Springer: Berlin/Heidelberg, Germany, 2006; pp. 51-93. ISBN 978-0-387-29655-5.

20. Myers, R.K.; van Lear, D.H. Hurricane-Fire Interactions in Coastal Forests of the South: A Review and Hypothesis. For. Ecol. Manag. 1998, 103, 265-276. [CrossRef]

21. Stanturf, J.A.; Goodrick, S.L.; Outcalt, K.W. Disturbance and Coastal Forests: A Strategic Approach to Forest Management in Hurricane Impact Zones. For. Ecol. Manag. 2007, 250, 119-135. [CrossRef]

22. Paudel, S.; Battaglia, L.L. Linking Responses of Native and Invasive Plants to Hurricane Disturbances: Implications for Coastal Plant Community Structure. Plant Ecol. 2021, 222, 133-148. [CrossRef]

23. Klepzig, K.; Shelfer, R.; Choice, Z. Outlook for Coastal Plain Forests: A Subregional Report from the Southern Forest Futures Project. Gen. Tech. Rep. 2014, 196, 1-68. [CrossRef] 
24. Anderson, C.J.; Lockaby, B.G. Soils and Biogeochemistry of Tidal Freshwater Forested Wetlands. In Ecology of Tidal Freshwater Forested Wetlands of the Southeastern United States; Conner, W.H., Doyle, T.W., Krauss, K.W., Eds.; Springer: Dordrecht, The Netherlands, 2007; pp. 65-88. ISBN 978-1-4020-5095-4.

25. Wharton, C.H. The Natural Environments of Georgia; Georgia Department of Natural Resources: Atlanta, GA, USA, 1978.

26. Brinson, M.M. Riverine Forests. In Ecosystems of the World 15: Forested Wetlands; Lugo, A.E., Brinson, M.M., Brown, S., Eds.; Elsevier: Amsterdam, The Netherlands, 1990; pp. 87-141.

27. Campbell, T.A.; Long, D.B. Feral Swine Damage and Damage Management in Forested Ecosystems. For. Ecol. Manag. 2009, 257, 2319-2326. [CrossRef]

28. Kaller, M.; Hudson, J.; Achberger, E.; Kelso, W. Feral Hog Research in Western Louisiana: Expanding Populations and Unforeseen Consequences. Hum. Wildl. Interact. 2007, 1, 168-177. [CrossRef]

29. Kaller, M.D.; Kelso, W.E. Swine Activity Alters Invertebrate and Microbial Communities in a Coastal Plain Watershed. Am. Midl. Nat. 2006, 156, 163-177. [CrossRef]

30. Newbold, J.D.; O’Neill, R.V.; Elwood, J.W.; Van Winkle, W. Nutrient Spiralling in Streams: Implications for Nutrient Limitation and Invertebrate Activity. Am. Nat. 1982, 120, 628-652. [CrossRef]

31. Mitchell, J.; Mayer, R. Diggings by Feral Pigs Within the Wet Tropics World Heritage Area of North Queensland. Wildl. Res. 1997, 24, 591-601. [CrossRef]

32. Wood, G.W.; Roark, D.N. Food Habits of Feral Hogs in Coastal South Carolina. J. Wildl. Manag. 1980, 44, 506-511. [CrossRef]

33. Dardaillon, M. Seasonal Feeding Habits of the Wild Boar in a Meditteranean Wetland, the Camargue (Southern France). Acta Theriol. 1987, 32, 389-401. [CrossRef]

34. Bruinderink, G.W.T.A.G.; Hazebroek, E. Wild Boar (Sus Scrofa Scrofa L.) Rooting and Forest Regeneration on Podzolic Soils in the Netherlands. For. Ecol. Manag. 1996, 88, 71-80. [CrossRef]

35. Bratton, S.P. The Effect of the European Wild Boar, Sus Scrofa, on Gray Beech Forest in the Great Smoky Mountains. Ecology 1975, 56, 1356-1366. [CrossRef]

36. Howe, T.D.; Singer, F.J.; Ackerman, B.B. Forage Relationships of European Wild Boar Invading Northern Hardwood Forest. J. Wildl. Manag. 1981, 45, 748-754. [CrossRef]

37. Lacki, M.J.; Lancia, R. Changes in Soil Properties of Forest Rooted by Wild Boar. In Proceedings of the Thirty-Seventh Annual Conference of the Southeastern Association of Fish and Wildlife Agencies, Ashville, NC, USA, 6-8 November 1983; pp. 228-236.

38. Lacki, M.J.; Lancia, R.A. Effects of Wild Pigs on Beech Growth in Great Smoky Mountains National Park. J. Wildl. Manag. 1986, 50, 655-659. [CrossRef]

39. Liu, Y.; Liu, X.; Yang, Z.; Li, G.; Liu, S. Wild Boar Grubbing Causes Organic Carbon Loss from Both Top- and Sub-Soil in an Oak Forest in Central China. For. Ecol. Manag. 2020, 464, 118059. [CrossRef]

40. Singer, F.J.; Swank, W.T.; Clebsch, E.E.C. Effects of Wild Pig Rooting in a Deciduous Forest. J. Wildl. Manag. 1984, 48, 464-473. [CrossRef]

41. Moody, A.; Jones, J.A. Soil Response to Canopy Position and Feral Pig Disturbance beneath Quercus Agrifolia on Santa Cruz Island, California. Appl. Soil Ecol. 2000, 14, 269-281. [CrossRef]

42. Mohr, D.; Cohnstaedt, L.W.; Topp, W. Wild Boar and Red Deer Affect Soil Nutrients and Soil Biota in Steep Oak Stands of the Eifel. Soil Biol. Biochem. 2005, 37, 693-700. [CrossRef]

43. Cushman, J.H.; Tierney, T.A.; Hinds, J.M. Variable Effects of Feral Pig Disturbances on Native and Exotic Plants in a California Grassland. Ecol. Appl. 2004, 14, 1746-1756. [CrossRef]

44. Tierney, T.A.; Cushman, J.H. Temporal Changes in Native and Exotic Vegetation and Soil Characteristics Following Disturbances by Feral Pigs in a California Grassland. Biol. Invasions 2006, 8, 1073-1089. [CrossRef]

45. Boughton, E.H.; Boughton, R.K. Modification by an Invasive Ecosystem Engineer Shifts a Wet Prairie to a Monotypic Stand. Biol. Invasions 2014, 16, 2105-2114. [CrossRef]

46. Ballari, S.A.; Barrios-García, M.N. A Review of Wild Boar Sus Scrofa Diet and Factors Affecting Food Selection in Native and Introduced Ranges. Mammal Rev. 2014, 44, 124-134. [CrossRef]

47. Gray, S.M.; Roloff, G.J.; Kramer, D.B.; Etter, D.R.; Vercauteren, K.C.; Montgomery, R.A. Effects of Wild Pig Disturbance on Forest Vegetation and Soils. J. Wildl. Manag. 2020, 84, 739-748. [CrossRef]

48. Persico, E.P.; Sharp, S.J.; Angelini, C. Feral Hog Disturbance Alters Carbon Dynamics in Southeastern US Salt Marshes. Mar. Ecol. Prog. Ser. 2017, 580, 57-68. [CrossRef]

49. Robeson, M.S.; Khanipov, K.; Golovko, G.; Wisely, S.M.; White, M.D.; Bodenchuck, M.; Smyser, T.J.; Fofanov, Y.; Fierer, N.; Piaggio, A.J. Assessing the Utility of Metabarcoding for Diet Analyses of the Omnivorous Wild Pig (Sus Scrofa). Ecol. Evol. 2018, 8, 185-196. [CrossRef]

50. Giménez-Anaya, A.; Herrero, J.; Rosell, C.; Couto, S.; García-Serrano, A. Food Habits of Wild Boars (Sus Scrofa) in a Mediterranean Coastal Wetland. Wetlands 2008, 28, 197-203. [CrossRef]

51. Pavlov, P.M.; Edwards, E.C. Feral Pig Ecology in Cape Tribulation National Park, North Queensland, Australia. J. Mt. Ecol. 2014, 3, 147-151.

52. Lavelle, P.; Decaëns, T.; Aubert, M.; Barot, S.; Blouin, M.; Bureau, F.; Margerie, P.; Mora, P.; Rossi, J.-P. Soil Invertebrates and Ecosystem Services. Eur. J. Soil Biol. 2006, 42, S3-S15. [CrossRef] 
53. Vanschoenwinkel, B.; Waterkeyn, A.; Vandecaetsbeek, T.; Pineau, O.; Grillas, P.; Brendonck, L. Dispersal of Freshwater Invertebrates by Large Terrestrial Mammals: A Case Study with Wild Boar (Sus Scrofa) in Mediterranean Wetlands. Freshw. Biol. 2008, 53, 2264-2273. [CrossRef]

54. Carpio, A.J.; Castro-López, J.; Guerrero-Casado, J.; Ruiz-Aizpurua, L.; Vicente, J.; Tortosa, F.S. Effect of Wild Ungulate Density on Invertebrates in a Mediterranean Ecosystem. Anim. Biodiv. Conserv. 2014, 37, 115-125. [CrossRef]

55. Wehr, N.H.; Litton, C.M.; Lincoln, N.K.; Hess, S.C. Relationships between Soil Macroinvertebrates and Nonnative Feral Pigs (Sus Scrofa) in Hawaiian Tropical Montane Wet Forests. Biol. Invasions 2020, 22, 577-586. [CrossRef]

56. Baron, J. Effects of Feral Hogs (Sus Scrofa) on the Vegetation of Horn Island, Mississippi. Am. Midl. Nat. 1982, 107, 202-205. [CrossRef]

57. Ickes, K.; Dewalt, S.J.; Appanah, S. Effects of Native Pigs (Sus Scrofa) on Woody Understorey Vegetation in a Malaysian Lowland Rain Forest. J. Trop. Ecol. 2001, 17, 191-206. [CrossRef]

58. Siemann, E.; Carrillo, J.A.; Gabler, C.A.; Zipp, R.; Rogers, W.E. Experimental Test of the Impacts of Feral Hogs on Forest Dynamics and Processes in the Southeastern US. For. Ecol. Manag. 2009, 258, 546-553. [CrossRef]

59. Hone, J. Feral Pigs in Namadgi National Park, Australia: Dynamics, Impacts and Management. Biol. Conserv. 2002, 105, 231-242. [CrossRef]

60. Fern, M.P.; Armstrong, J.B.; Barlow, R.J.; Kush, J.S. Ecological Factors Influencing Wild Pig Damage to Planted Pine and Hardwood Seedlings. Hum. Wildl. Interact. 2020, 14, 11. [CrossRef]

61. Bratton, S.P. The Effect of the European Wild Boar (Sus Scrofa) on the High-Elevation Vernal Flora in Great Smoky Mountains National Park. Bull. Torrey Bot. Club 1974, 101, 198-206. [CrossRef]

62. Kotanen, P.M. Responses of Vegetation to a Changing Regime of Disturbance: Effects of Feral Pigs in a Californian Coastal Prairie. Ecography 1995, 18, 190-199. [CrossRef]

63. Evans, J.P.; Keen, E.M. Regeneration Failure in a Remnant Stand of Pignut Hickory (Carya Glabra) on a Protected Barrier Island in Georgia, USA. Nat. Areas J. 2013, 33, 171-176. [CrossRef]

64. Welander, J. Spatial and Temporal Dynamics of Wild Boar (Sus Scrofa) Rooting in a Mosaic Landscape. J. Zool. 2000, $252,263-271$. [CrossRef]

65. Engeman, R.M.; Smith, H.T.; Shwiff, S.A.; Constantin, B.; Woolard, J.; Nelson, M.; Griffin, D. Prevalence and Economic Value of Feral Swine Damage to Native Habitat in Three Florida State Parks. Environ. Conserv. 2003, 30, 319-324. [CrossRef]

66. Engeman, R.M.; Orzell, S.L.; Felix, R.K.; Tillman, E.A.; Killian, G.; Avery, M.L. Feral Swine Damage to Globally Imperiled Wetland Plant Communities in a Significant Biodiversity Hotspot in Florida. Biodivers. Conserv. 2016, 25, 1879-1898. [CrossRef]

67. Engeman, R.M.; Smith, H.T.; Severson, R.; Ann Severson, M.; Shwiff, S.A.; Constantin, B.; Griffin, D. The Amount and Economic Cost of Feral Swine Damage to the Last Remnant of a Basin Marsh System in Florida. J. Nat. Conserv. 2004, 12, 143-147. [CrossRef]

68. Mooney, H.A.; Cleland, E.E. The Evolutionary Impact of Invasive Species. Proc. Natl. Acad. Sci. USA 2001, 98, 5446-5451. [CrossRef]

69. Barrios-Garcia, M.N.; Simberloff, D. Linking the Pattern to the Mechanism: How an Introduced Mammal Facilitates Plant Invasions. Austral. Ecol. 2013, 38, 884-890. [CrossRef]

70. Simberloff, D.; Von Holle, B. Positive Interactions of Nonindigenous Species: Invasional Meltdown? Biol. Invasions 1999, 1, $21-32$. [CrossRef]

71. Lynes, B.C.; Cambell, S.D. Germination and Viability of Mesquite (Prosopis Pallida) Seed Following Ingestion and Excretion by Feral Pigs (Sus Scrofa). Trop. Grassl. 2000, 34, 125-128.

72. Dovrat, G.; Perevolotsky, A.; Ne'eman, G. Wild Boars as Seed Dispersal Agents of Exotic Plants from Agricultural Lands to Conservation Areas. J. Arid Environ. 2012, 78, 49-54. [CrossRef]

73. Schmidt, M.; Sommer, K.; Kriebitzsch, W.-U.; Ellenberg, H.; von Oheimb, G. Dispersal of Vascular Plants by Game in Northern Germany. Part I: Roe Deer (Capreolus Capreolus) and Wild Boar (Sus Scrofa). Eur. J. For. Res. 2004, 123, 167-176. [CrossRef]

74. Beasley, J.C.; Grazia, T.E.; Johns, P.E.; Mayer, J.J. Habitats Associated with Vehicle Collisions with Wild Pigs. Wildl. Res. 2014, 40, 654-660. [CrossRef]

75. Mack, M.C.; D'Antonio, C.M. Impacts of Biological Invasions on Disturbance Regimes. Trends Ecol. Evol. 1998, 13, 195-198. [CrossRef]

76. Rejmánek, M.; Richardson, D.M. What Attributes Make Some Plant Species More Invasive? Ecology 1996, 77, 1655-1661. [CrossRef]

77. Ralph, C.J.; Maxwell, B.D. Relative Effects on Human and Feral Hog Disturbance on a Wet Forest in Hawaii. Biol. Conserv. 1984, 30, 291-303. [CrossRef]

78. Aplet, G.H.; Anderson, S.J.; Stone, C.P. Association between Feral Pig Disturbance and the Composition of Some Alien Plant Assemblages in Hawaii Volcanoes National Park. Vegetatio 1991, 95, 55-62. [CrossRef]

79. Barrios-Garcia, M.N.; Classen, A.T.; Simberloff, D. Disparate Responses of Above- and Belowground Properties to Soil Disturbance by an Invasive Mammal. Ecosphere 2014, 5, art44. [CrossRef]

80. Oldfield, C.A.; Evans, J.P. Twelve Years of Repeated Wild Hog Activity Promotes Population Maintenance of an Invasive Clonal Plant in a Coastal Dune Ecosystem. Ecol. Evol. 2016, 6, 2569-2578. [CrossRef]

81. D'Antonio, C.; Flory, S.L. Long-Term Dynamics and Impacts of Plant Invasions. J. Ecol. 2017, 105, 1459-1461. [CrossRef]

82. Grove, S.; Haubensak, K.A.; Gehring, C.; Parker, I.M. Mycorrhizae, Invasions, and the Temporal Dynamics of Mutualism Disruption. J. Ecol. 2017, 105, 1496-1508. [CrossRef] 
83. Gilbert, B.; Levine, J.M. Plant Invasions and Extinction Debts. Proc. Natl. Acad. Sci. USA 2013, 110, 1744-1749. [CrossRef]

84. Soteras, F.; Ibarra, C.; Geml, J.; Barrios-García, M.N.; Domínguez, L.S.; Nouhra, E.R. Mycophagy by Invasive Wild Boar (Sus Scrofa) Facilitates Dispersal of Native and Introduced Mycorrhizal Fungi in Patagonia, Argentina. Fungal Ecol. 2017, $26,51-58$. [CrossRef]

85. Anderson, A.; Slootmaker, C.; Harper, E.; Miller, R.S.; Shwiff, S.A. Predation and Disease-Related Economic Impacts of Wild Pigs on Livestock Producers in 13 States. Crop Prot. 2019, 121, 121-126. [CrossRef]

86. Corn, J.L.; Yabsley, M.J. Diseases and Parasites That Impact Wild Pigs and Species They Contact. In Invasive Wild Pigs in North America: Ecology, Impacts and Management; VerCauteren, K.C., Beasley, J.C., Ditchkoff, S.S., Mayer, J.J., Roloff, G.J., Strickland, B.K., Eds.; CRC Press: Boca Raton, FL, USA, 2019; pp. 83-126. ISBN 978-1-315-23305-5.

87. Miller, R.S.; Sweeney, S.J.; Slootmaker, C.; Grear, D.A.; Di Salvo, P.A.; Kiser, D.; Shwiff, S.A. Cross-Species Transmission Potential between Wild Pigs, Livestock, Poultry, Wildlife, and Humans: Implications for Disease Risk Management in North America. Sci. Rep. 2017, 7, 7821. [CrossRef] [PubMed]

88. Jamieson, R.C.; Gordon, R.J.; Sharples, K.E.; Madani, A.; Stratton, G.W. Movement and Persistence of Fecal Bacteria in Agricultural Soils and Subsurface Drainage Water: A Review. Can. Biosyst. Eng. Genie Biosyst. Can. 2002, 44, 1.1-1.9.

89. Doupé, R.G.; Mitchell, J.; Knott, M.J.; Davis, A.M.; Lymbery, A.J. Efficacy of Exclusion Fencing to Protect Ephemeral Floodplain Lagoon Habitats from Feral Pigs (Sus Scrofa). Wetl. Ecol. Manag. 2010, 18, 69-78. [CrossRef]

90. Bolds, S.A.; Lockaby, B.G.; Ditchkoff, S.S.; Smith, M.D.; VerCauteren, K.C. Impacts of a Large Invasive Mammal on Water Quality in Riparian Ecosystems. J. Environ. Qual. 2021, 50, 441-453. [CrossRef]

91. Brooks, J.P.; Smith, R.K.; Aldridge, C.A.; Chaney, B.; Omer, A.; Dentinger, J.; Street, G.M.; Baker, B.H. A Preliminary Investigation of Wild Pig (Sus Scrofa) Impacts in Water Quality. J. Environ. Qual. 2020, 49, 27-37. [CrossRef]

92. Crim, J.F.; Schoonover, J.E.; Lockaby, B.G. Assessment of Fecal Coliform and Escherichia Coli Across a Land Cover Gradient in West Georgia Streams. Water Qual. Expo. Health 2012, 4, 143-158. [CrossRef]

93. Petersen, F.; Hubbart, J.A. Physical Factors Impacting the Survival and Occurrence of Escherichia Coli in Secondary Habitats. Water 2020, 12, 1796. [CrossRef]

94. Holling, C.S. Resilience and Stability of Ecological Systems. Annu. Rev. Ecol. Syst. 1973, 4, 1-23. [CrossRef]

95. Burkett, V.; Ritschard, R.; McNulty, S.; O’Brien, J.J.; Abt, R.C.; Jones, J.; Hatch, U.; Murray, B.; Jagtap, S.; Cruise, J. Potential consequences of climate variability and change for the Southeastern United States. In Climate Change Impacts on the United States: The Potential Consequences of Climate Variability and Change: Foundation Report; Cambridge University Press: Cambridge, UK, 2001; pp. 137-164.

96. Susaeta, A.; Carter, D.R.; Adams, D.C. Impacts of Climate Change on Economics of Forestry and Adaptation Strategies in the Southern United States. J. Agric. Appl. Econ. 2014, 46, 257-272. [CrossRef]

97. Joyce, L.A.; Coulson, D. Climate Scenarios and Projections: A Technical Document Supporting the USDA Forest Service 2020 RPA Assessment. Gen. Tech. Rep. 2020, 413, 85. [CrossRef]

98. Mcnulty, S.; Threat, E.F.E.; Service, F.; Service, U.F.; Carolina, P.N. Forests and Climate Change in the Southeast USA. In Climate of the Southeast United States; United States Forest Service: Washington, DC, USA, 2013; Chapter 8.

99. Liu, J.; Niyogi, D. Meta-Analysis of Urbanization Impact on Rainfall Modification. Sci. Rep. 2019, 9, 7301. [CrossRef]

100. USGCRP. Fourth National Climate Assessment; U.S. Global Change Research Program: Washington, DC, USA, $2018 ;$ pp. 1-470.

101. Carter, L.; Terando, A.J.; Dow, K.; Hiers, K.; Kunkel, K.E.; Lascurain, A.R.; Marcy, D.; Osland, M.J.; Schramm, P. Southeast; U.S. Global Change Research Program: Washington, DC, USA, 2018; p. 743808.

102. Wear, D.N.; Greis, J.G. The Southern Forest Futures Project: Technical Report. Gen. Tech. Rep. 2013, 178, 1-542. [CrossRef]

103. Doyle, T.W. Hurricane Frequency and Landfall Distribution for Coastal Wetlands of the Gulf Coast, USA. Wetlands 2009, 29 , 35-43. [CrossRef]

104. Bisi, F.; Chirichella, R.; Chianucci, F.; Von Hardenberg, J.; Cutini, A.; Martinoli, A.; Apollonio, M. Climate, Tree Masting and Spatial Behaviour in Wild Boar (Sus Scrofa L.): Insight from a Long-Term Study. Ann. For. Sci. 2018, 75, 46. [CrossRef]

105. Espelta, J.M.; Cortés, P.; Molowny-Horas, R.; Sánchez-Humanes, B.; Retana, J. Masting Mediated by Summer Drought Reduces Acorn Predation in Mediterranean Oak Forests. Ecology 2008, 89, 805-817. [CrossRef]

106. Stohlgren, T.J.; Barnett, D.T.; Kartesz, J.T. The Rich Get Richer: Patterns of Plant Invasions in the United States. Front. Ecol. Environ. 2003, 1, 11-14. [CrossRef]

107. Paudel, S.; Battaglia, L.L. The Role of Light, Soil and Human Factors on the Probability of Occurrence of an Invasive and Three Native Plant Species in Coastal Transitions of Coastal Mississippi, USA. J. Plant Ecol. 2015, 8, 491-500. [CrossRef]

108. Parendes, L.A.; Jones, J.A. Role of Light Availability and Dispersal in Exotic Plant Invasion along Roads and Streams in the H. J. Andrews Experimental Forest, Oregon. Conserv. Biol. 2000, 14, 64-75. [CrossRef]

109. Mortensen, D.A.; Rauschert, E.S.J.; Nord, A.N.; Jones, B.P. Forest Roads Facilitate the Spread of Invasive Plants. Invasive Plant Sci. Manag. 2009, 2, 191-199. [CrossRef]

110. Clontz, L.M.; Pepin, K.M.; VerCauteren, K.C.; Beasley, J.C. Behavioral State Resource Selection in Invasive Wild Pigs in the Southeastern United States. Sci. Rep. 2021, 11, 6924. [CrossRef]

111. Pickett, B.; Maltz, M.; Aronson, E. Impacts of Invasive Plants on Soil Fungi and Implications for Restoration. In Diversity and Ecology of Invasive Plants; Books on Demand: Norderstedt, Germany, 2018. 
112. Dickie, I.A.; Bufford, J.L.; Cobb, R.C.; Desprez-Loustau, M.-L.; Grelet, G.; Hulme, P.E.; Klironomos, J.; Makiola, A.; Nuñez, M.A.; Pringle, A.; et al. The Emerging Science of Linked Plant-Fungal Invasions. New Phytol. 2017, 215, 1314-1332. [CrossRef]

113. Batten, K.M.; Scow, K.M.; Espeland, E.K. Soil Microbial Community Associated with an Invasive Grass Differentially Impacts Native Plant Performance. Microb. Ecol. 2008, 55, 220-228. [CrossRef]

114. Mangla, S.; Callaway, R.M. Exotic Invasive Plant Accumulates Native Soil Pathogens Which Inhibit Native Plants. J. Ecol. 2008, 96, 58-67. [CrossRef]

115. Jamieson, M.A.; Trowbridge, A.M.; Raffa, K.F.; Lindroth, R.L. Consequences of Climate Warming and Altered Precipitation Patterns for Plant-Insect and Multitrophic Interactions. Plant Physiol. 2012, 160, 1719-1727. [CrossRef]

116. Linnakoski, R.; Kasanen, R.; Dounavi, A.; Forbes, K.M. Editorial: Forest Health Under Climate Change: Effects on Tree Resilience, and Pest and Pathogen Dynamics. Front. Plant Sci. 2019, 10, 1157. [CrossRef]

117. Proesmans, W.; Albrecht, M.; Gajda, A.; Neumann, P.; Paxton, R.J.; Pioz, M.; Polzin, C.; Schweiger, O.; Settele, J.; Szentgyörgyi, H.; et al. Pathways for Novel Epidemiology: Plant-Pollinator-Pathogen Networks and Global Change. Trends Ecol. Evol. 2021, 36, 623-636. [CrossRef]

118. Flanagan, N.E.; Richardson, C.J.; Ho, M. Connecting Differential Responses of Native and Invasive Riparian Plants to Climate Change and Environmental Alteration. Ecol. Appl. 2015, 25, 753-767. [CrossRef] [PubMed]

119. Nagy, R.C.; Lockaby, B.G. Urbanization in the Southeastern United States: Socioeconomic Forces and Ecological Responses along an Urban-Rural Gradient. Urban Ecosyst 2011, 14, 71-86. [CrossRef] 